\title{
Design Of Website-Based Santri Attendance Information System (Case Study: Rumah Yatim And Tahfidz Qur'an Madani Bandung)
}

\author{
Mamok Andri Senubekti \\ Departement of Informatic Management \\ HASS Bandung Academy of Informatics and Computer \\ Management \\ Bandung, Indonesia \\ mrymodion@gmail.com
}

\author{
Muhammad Yusron Fathul Islam \\ Departement of Informatic Management \\ HASS Bandung Academy of Informatics and Computer \\ Management \\ Bandung, Indonesia \\ muhammadyusron10.khanus@gmail.com
}

\begin{abstract}
In today's era of globalization, the advancement of information technology is accelerating. Computers connected to the internet or intranet created to facilitate human work are needed in all fields, especially in the field of education. Rumah Yatim and Tahfidz Qur'an Madani need a website-based attendance information system to help enter santri attendance data. For this reason, the author tried to create a journal about a web-based santri absence system that until now has not been computerized. Rumah Yatim and Tahfidz Qur'an Madani is one of the foundations in Bandung that until now the input of absenteeism is still manual ranging from the input of santri absentee data to the storage of absentee data that has been input and report making. So that it is possible when the process takes place data manipulation and data loss is very large. The design of this information system is the best solution to solve the problems in this foundation, and with a computerized system can be achieved an effective and efficient activity in supporting activities in this foundation.
\end{abstract}

Keywords- Information System Design, Absence of webbased santri.

\section{INTRODUCTION (HEADING 1)}

\subsection{Background}

The development of information and communication technology greatly influenced today's civilization, allowing the work within a foundation to be completed quickly, accurately and efficiently. One example is the santri absentee taking system, in some schools the santri absentee taking system is still manual or still uses an absentee card. If we follow the development of technology today that has been increasingly advanced or developing, of course, there are many examples of technological developments that will be encountered, one example of technological development is the Website. The website is static if the content of the website information remains, rarely changes and the content of the information is in the direction only from the website owner. The website is dynamic if the content of the website information is always changing, and the content of the information is interactive both ways from the owner and users of the Website. Rumah Yatim and Tahfidz Qur'an Madani have a website that is generally accessible to everyone, is www.rumahyatimmadani.com that contains a foundation profile. But do not have a santri absenteeee collection website, since February 17, 2019 the author joined this foundation, and this is the main reason the author conducted
Work Practices in Orphan Homes and Tahfidz Qur'an Madani. In its development, Rumah Yatim and Tahfidz Qur'an Madani have used the use of information technology in various aspects of the foundation's operational activities. But it does not include the taking of absenteeism santri who are still manual or still use the absentee card. In this article, the author is interested in compiling a Case Study Report with the title "Design of Website-Based Santri Attendance Information System in Rumah Yatim and Tahfidz Qur'an Madani Bandung".

\subsection{Identify problems}

1. The research problems that the author proposes can be identified as follows:

2. There is no absence of website-based santri. Absentee santri still uses a manual way so it takes a long time.

\subsection{Research objectives}

The purpose of the research is to:

1. Preparing an efficient santri absence application and can facilitate the teacher's work in the input of absentee santri.

2. Make it easier for teachers to recapitulate absentee santri

3. Make it easier for the foundation to inform parents about santri absences.

\subsection{Scope of Research}

In the writing of this Journal, the author limited its scope only to designing and creating a web-based santri absence application system, which also includes its activities in online attendance activities ranging from inputting teacher data conducted by admins, teachers choosing classes to be licensed, adding new santri data in class to the process of making periodic attendance recapitulation reports given to classroom guardians. Print the attendance recapitulation report can only be done by the teacher.

\subsection{Research Methods}

As for the research methods that the author did in the making of this Journal, the author conducted research in the Orphanage and Tahfidz Qur'an Madani are:

1. Interview Technique. 
The author conducted a direct Q\&A with Ustadz Maman Suryaman S.E as the chairman of the Orphanage and Tahfidz Qur'an Madani.

2. Observation technique.

During the research, the author made direct observations to the Orphanage and Tahfidz Qur'an Madani on the absence activities carried out before teaching and learning activities.

3. Literature Studies.

With this method of literature study, the author gets data sources from books and journals that relate to the title that the author raised and used for reference related to the design of the program application.

\section{METHODS}

\subsection{Framework}

To help in the preparation of this research, it is necessary to have a clear frame work arrangement. This framework is the steps that will be taken in solving the problem that will be discussed. As for the research framework used as seen in the picture:

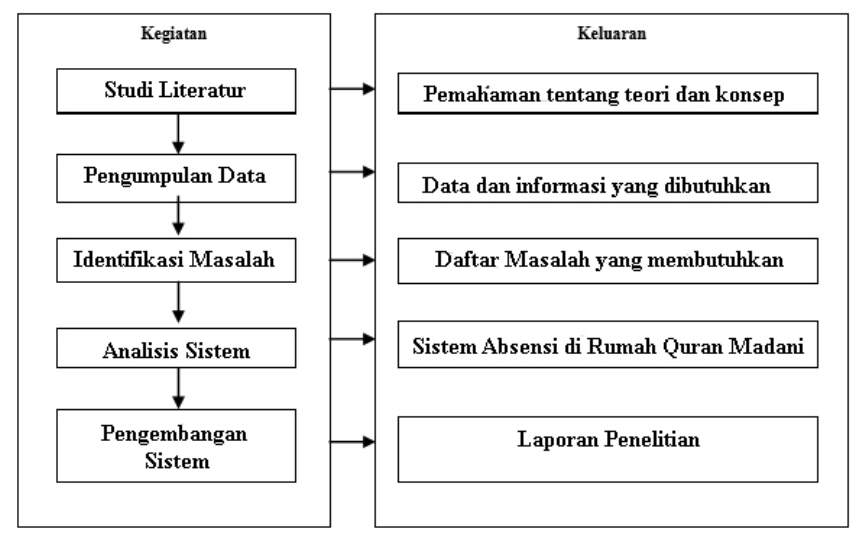

Fig 1. Research Framework

\subsubsection{Literature Studies}

At this stage, a search of theoretical foundations obtained from various books and also the internet to complement the treasury of concepts and theories, so as to have a good and appropriate foundation and science. Data Collection

At this stage, the process of collecting data with interview and observation methods to make observations and analysis of the ongoing teaching-learning process at Sweet School Batam so as to get the data and information needed by researchers.

\subsubsection{System Analysis}

At this stage, identification of problems in the system is being carried out. Thus, it is expected that researchers can find obstacles and problems that occur in the teachinglearning process in the Orphanage and Tahfidz Qur'an Madani so that researchers can find solutions to these problems.

\subsubsection{System Development}

At this stage, system development is carried out using the waterfall model.

\subsubsection{Report Creation}

At this stage, a report is made based on the results of research using primary and secondary data collection techniques so that it becomes a research report that can provide a complete picture of the system being built.

\subsection{Data Collection Methods}

For the preparation of this Journal, data and information related to the title are needed, namely "Website-Based Santri Attendance Information System in Orphan House and Tahfidz Qur'an Madani". Therefore, before the preparation of this Journal is done research or research first to net data and related information. The methods of data collection carried out in the writing of this thesis, among others:

\subsubsection{Library Studies}

According to Iyas (2011), library studies are conducted by searching for books, magazines or brochures related to research, scientific works or journals, articles, both in the library and on the internet. The data derived from books and the internet that are used as references in the preparation of this thesis are the theories contained in chapter 2 of this Journal.

\subsubsection{Field Studies}

According to Iyas (2011), the methodology carried out in field studies is to practice into the field directly to obtain information related to research. Practices carried out in field studies, among others:

a. Observation

The author analyzes existing problems by observing the source and processing of data and collecting data from parts related to the teacher and santri absenteeism system in the Orphan House and Tahfidz Qur'an Madani, observations are made to see firsthand the ongoing work process.

b. Interview

The interview method is a method of collecting data by doing direct Q\&A with Ustadz Maman Suryaman S.E as the chairman of Rumah Yatim and Tahfidz in Bandung.

\subsection{System Approach Methods}

System approach method is an approach by how to use tools and regulations that complement one or more stages of information system development. The system approach method used in the creation of absentee information systems is by way of a structured approach that is oriented to data, namely structured analysis and design. A structured approach is the development of systems that follow the stages of system development with data collection tools and techniques. The tools used as aids are as follows:

\section{FlowChart}

Flowchart or flowchart is a diagram with graphical symbols that state the flow of algorithms or processes that display the steps symbolized in the form of boxes, along with the sequence by connecting each step using arrows.

2. UML or Unified Modelling Language Unified Modeling Language is a method of visual modeling for the means of designing object-oriented systems, or the definition of UML as a language that has 
become the standard for visualization, design and also documenting software systems. The types of UML diagrams are:

a. Use case diagram

Use case diagram is a diagram that describes the interaction between the system and the actor, the use case diagram can also describe the type of interaction between the user of the system and the system.

b. Activity Diagram

Activity diagram is a type of diagram on UML that can model any processes that occur in the system.

c. Class Diagram

Class diagram is a type of diagram on UML that is used to display classes and packages that exist in a system to be used. The diagram can give an idea of the system and its relationships.

\subsection{History of Orphan House and Tahfidz Qur'an Madani}

Since about June 2012, the House of Qur'an Madani (RQM) which is addressed in Kiara Sari VII no.24, has been running. Hopefully, the House of Qur'an Madani produces students (scholarships) who memorize the Qur'an 30 Juz. And it's covered.

Management of results (targets). Tahfidz achievements should be closely guarded quarterly. The students undergo an exam to find out the achievement and evaluation of other results in general.

Teacher management (ustadz) and the replacement of the teaching team (Asatidz) with function updates. Teachers and replacement teams are those who are ready to accompany the tahfidz students and be role models (especially in the issue of tahfidz).

In the end, only the pleasure of Allah SWT we expect, and with the help of Allah SWT all efforts will feel light. The house of the Qur'an Madani was established with a very noble ideal, which is to form generations of Qur'an for the creation of a broader purpose, which is to create a civil society. This Madani Qur'an house was established under the new Indonesian Civil Society Foundation (YMMB) chaired by Dr. Ir. H. Muhammad Budi Djatmiko M.Si.

\section{RESULTS AND DISCUSSION}

\subsection{Problems}

During the author's stay in the Orphanage and Tahfidz Qur'an Madani that is for 2 years. The author found the problem in the dormitory is that the santri absence process still uses manual methods, namely still writing in the absentee book, and the author also saw a lot of shortcomings such as the loss of previous santri absence data, or the breakdown of absenteeism due to exposure to water.

\subsection{The solution}

The author makes a santri absence design but based on the web, in the design we can see the system in this design is very effective, because the author makes several admins to control the santri absence process. So there will be no data loss or data damage, because all data is already stored in the application.

\subsection{Analysis of Ongoing Systems}

Analysis of ongoing procedures systematically describes the activities that occur in the process of santri absence.

\subsection{Analysis of Ongoing Systems}

Analysis of ongoing procedures systematically describes the activities that occur in the process of santri absence.

\subsubsection{Use Case Diagram Running}

A use case diagram is modeling to describe an interaction between one or more actors in an ongoing system. Use cases are used to find out what functions are in an information system and who has the right to use those functions. Here's a depiction of a running use case for an absentee information system.

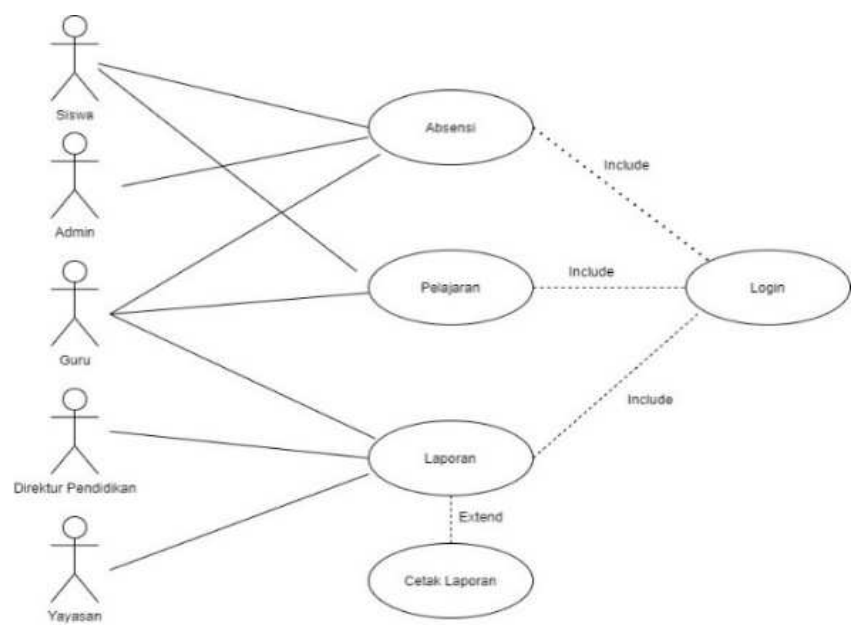

Fig 2. Use Case Diagram

\subsection{Running Activity Diagram}

Activity diagrams describe the various flow of activity in the system being designed. Activity diagrams can also describe parallel processes that may occur in some executions. Here is an activity diagram image of the ongoing absenteeism process:

1. Santri attended the Teaching and Learning Activities room

2. The teacher came into the room.

3. The teacher did absenteeism to the students who were present, sick, or santri without information.

4. Teachers collect absenteeism data

5. The teacher makes a report and provides the results of the report to the director of education.

6. The director of education checks the attendance data, whether there are absentee violations committed by the santri

7. If no breach is found, the education director will archive the attendance data. 


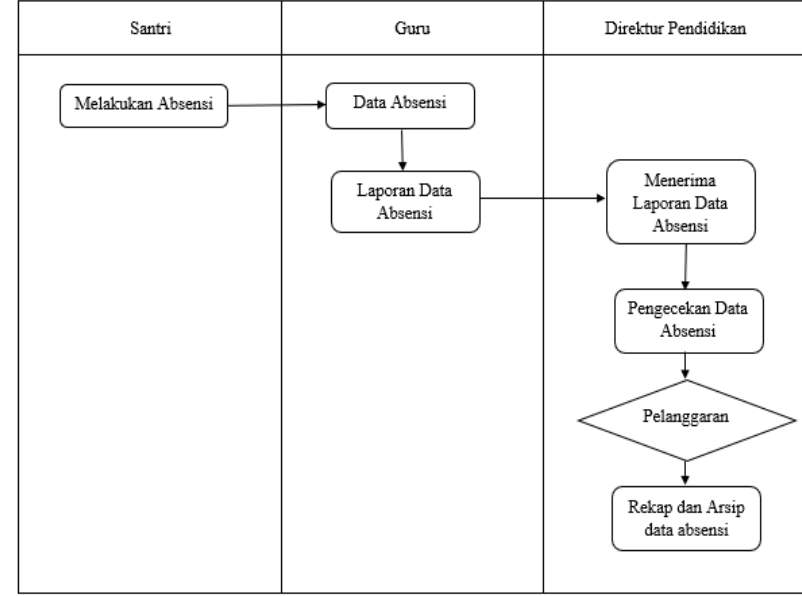

Fig. 3 Activity Diagram of Absentee Procedures on Running Systems

\subsection{Class Diagram}

Class diagrams are specifications that if in instance will produce an object and are the core of object-oriented development and design. Class diagrams describe the state (attributes/properties) of a system, while offering services to manipulate those circumstances (methods/functions).

\begin{tabular}{|l|}
\hline \multicolumn{1}{|c|}{ Guru } \\
\hline + id guru : int \\
+ nama guru: varchar \\
+ jenis kelamin : varchar \\
+ telepon : int \\
\hline + absensi 0 \\
+ pelajaran 0 \\
+ laporan 0) \\
+ cetaklaporan () \\
\hline
\end{tabular}
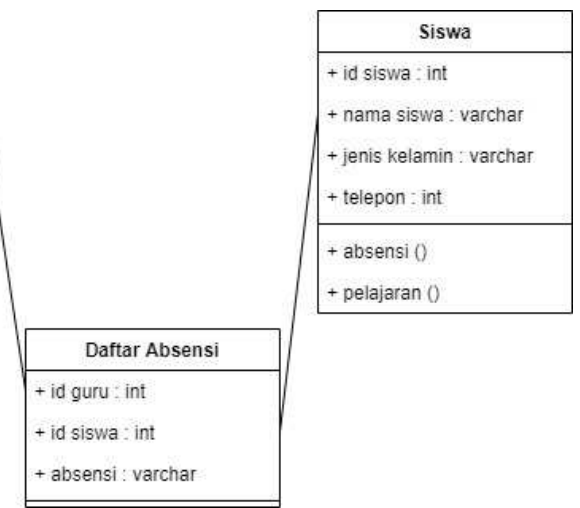

Fig. 4 Class Diagram

\subsection{Table Structure}

\subsubsection{Teacher}

This table is used for teachers who are in an institution or school. This table consists of: id guru, nip, nuptk, name, jenis_kelamin, status, address, job title, telephone, tgl_lahir.

Table name: teacher

Primary Key: id_guru

\section{Table 1 Teacher}

\begin{tabular}{|l|l|l|l|}
\hline \multicolumn{1}{|c|}{ Nama Field } & \multicolumn{1}{c|}{ Panjang } & \multicolumn{1}{c|}{ Type } & Keterangan \\
\hline Id_guru & 5 & Int & Primary Key \\
\hline Nip & 5 & Varchar & \\
\hline Nuptk & 5 & Varchar & \\
\hline Nama & 30 & Varchar & \\
\hline Jenis_kelamin & 1 & Varchar & \\
\hline Status & 20 & Varchar & \\
\hline Alamat & 100 & Varchar & \\
\hline Jabatan & 20 & Varchar & \\
\hline Telepon & 15 & Varchar & \\
\hline Tgl_lahir & & Date & \\
\hline
\end{tabular}

\subsubsection{Student}

This table is used to find out the students who are in an institution or school. This table consists of: id_siswa, name, jenis_kelamin, class, address, tgl_lahir, telephone

Table name: student

Primary Key: id_siswa

Table 2 Student

\begin{tabular}{|l|l|l|l|}
\hline \multicolumn{1}{|c|}{ Nama Field } & \multicolumn{1}{c|}{ Panjang } & \multicolumn{1}{c|}{ Type } & Keterangan \\
\hline Id_siswa & 5 & Int & Primary Key \\
\hline Nama & 50 & Varchar & \\
\hline Jenis_kelamin & 1 & Varchar & \\
\hline Kelas & 11 & Int & \\
\hline Alamat & 100 & Varchar & \\
\hline Tgl_lahir & & Date & \\
\hline Telepon & 15 & Varchar & \\
\hline
\end{tabular}

\subsubsection{User}

This table is used to find out who can login in an application. This table consists of: id_user, username, password, name, email, access

Table name: user

Primary Key: id_user

Table 3 User

\begin{tabular}{|l|l|l|l|}
\hline \multicolumn{1}{|c|}{ Nama Field } & Panjang & \multicolumn{1}{c|}{ Type } & Keterangan \\
\hline id_user & 5 & Int & Primary Key \\
\hline Username & 5 & Varchar & \\
\hline Password & 15 & Varchar & \\
\hline Nama & 30 & Varchar & \\
\hline Email & 50 & Varchar & \\
\hline Akses & 15 & Varchar & \\
\hline
\end{tabular}

\subsubsection{Absen_siswa}

This table is used for absent students in an institution or school. This table consists of: id absen siswa, tgl absen, description, id_siswa.

Table name: absen siswa

Primary Key: id_absen_siswa

Table 4 Student absence

\begin{tabular}{|l|l|l|l|}
\hline \multicolumn{1}{|c|}{$\begin{array}{c}\text { Nama } \\
\text { Field }\end{array}$} & \multicolumn{1}{|c|}{ Panjang } & \multicolumn{1}{c|}{ Type } & \multicolumn{1}{c|}{ Keterangan } \\
\hline $\begin{array}{l}\text { Id_absen_- } \\
\text { Siswa }\end{array}$ & 5 & Int & Primary Key \\
\hline \multicolumn{1}{|c|}{ Tgl_absen } & & Date & \\
\hline Keterangan & 1 & Varchar & \\
\hline Id_siswa & 5 & Int & Foreign Key \\
\hline
\end{tabular}

\subsubsection{Class}

These tables are used for classes used in an institution or school. This table consists of: id kelas, class name Table name: class Primary Key: id_kelas

Table 5 Classes

\begin{tabular}{|l|l|l|l|}
\hline \multicolumn{1}{|c|}{ Nama Field } & \multicolumn{1}{|c|}{ Panjang } & \multicolumn{1}{c|}{ Type } & Keterangan \\
\hline id_kelas & 5 & Int & Primary Key \\
\hline Nama kelas & 30 & Varchar & \\
\hline
\end{tabular}


BEST

Journal of Applied Electrical \& Science Technology - University of PGRI Adi Buana Surabaya

\subsubsection{Lesson}

This table is used to find out the lesson schedule that is in an institution or school. This table consists of: id_pelajaran, mata_pelajaran

Table name: id_pelajaran

Primary Key: mata pelajaran

Table 6 lessons

\begin{tabular}{|l|l|l|l|}
\hline \multicolumn{1}{|c|}{ Nama Field } & \multicolumn{1}{|c|}{ Panjang } & \multicolumn{1}{c|}{ Type } & \multicolumn{1}{c|}{ Keterangan } \\
\hline id pelajaran & 5 & Int & Primary Key \\
\hline Mata_pela-jaran & 30 & Varchar & \\
\hline
\end{tabular}

\subsection{Specifications of Hardware and Software}

Hardware and software specifications required for the creation of web-based santri absences, as in the table below

Table 7 Hardware and Software Specifications

\begin{tabular}{|l|l|}
\hline \multicolumn{1}{|c|}{ Kebutuhan } & \multicolumn{1}{c|}{ Keterangan } \\
\hline Device Name & DESKTOP-GV4I425 \\
\hline Sistem Operasi & Windows 10 Pro 64-bit \\
\hline Processor & $\begin{array}{l}\text { AMD A9-9425 RADEON R5, 5 } \\
\text { COMPUTE CORES 2C+3G }\end{array}$ \\
\hline RAM & 4 GB \\
\hline Hard Disk & 1 TB \\
\hline Keyboard & Qwerty \\
\hline Mouse & Wireless \\
\hline Software & $\begin{array}{l}\text { Google Chrome, XAMPP, Sublime } \\
\text { Text 3 }\end{array}$ \\
\hline
\end{tabular}

\subsection{Implementation Results}

The implementation results of several configurations carried out on the creation of this website can be viewed using a web browser. The web browser used is Chrome, by typing the following link http://localhost/absensi2. The following are some views of the results of the implementation of the design of the website-based santri attendance information system at Rumah Yatim and Tahfidz Qur'an Madani Bandung

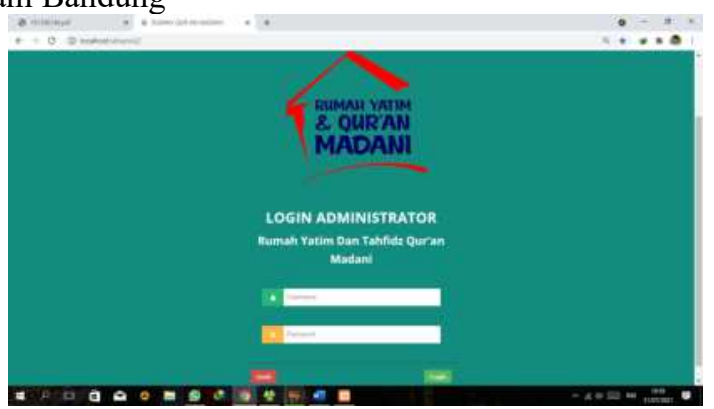

Fig. 5 Login Menu

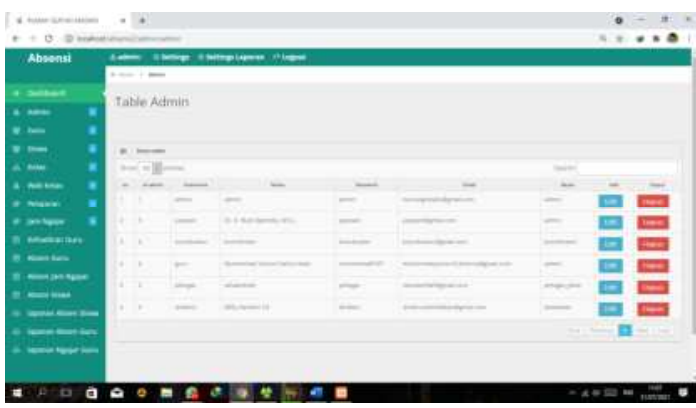

Fig. 6 Table Admin

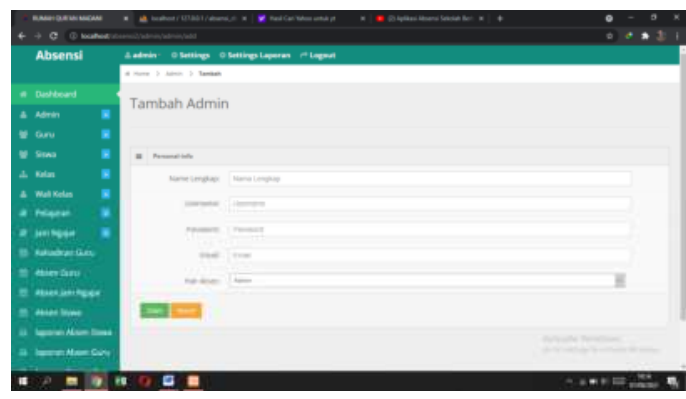

Fig. 7 Add Admin

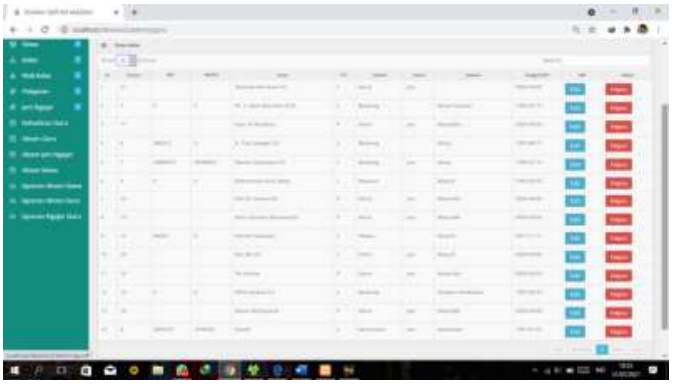

Fig. 8 Teacher Table

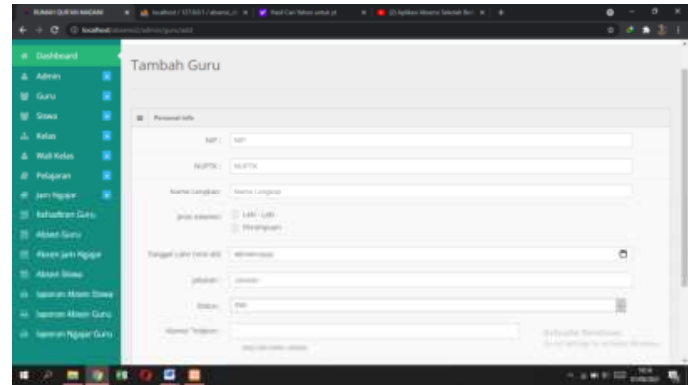

Fig. 9 Add Teacher

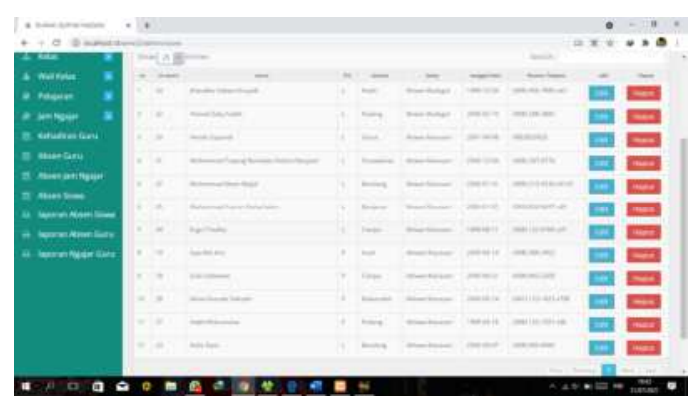

Fig. 10 Santri Table

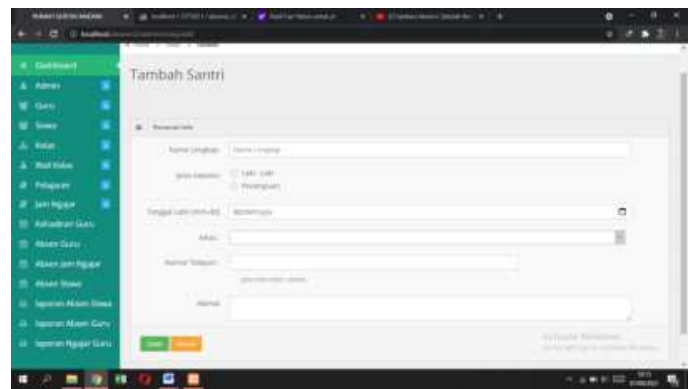

Fig. 11 Add Santri 


\section{BEST}

Journal of Applied Electrical \& Science Technology - University of PGRI Adi Buana Surabaya

p-ISSN 2715-2871

e-ISSN 2714-5247

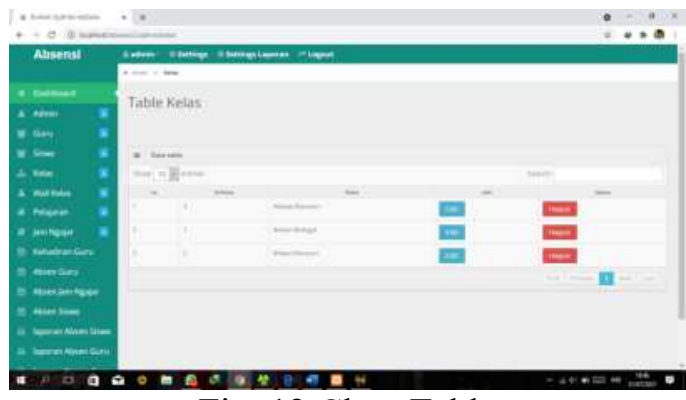

Fig. 12 Class Table

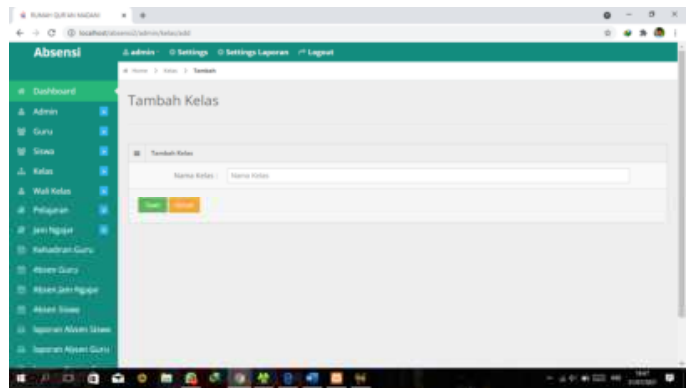

Fig. 13 Add Class

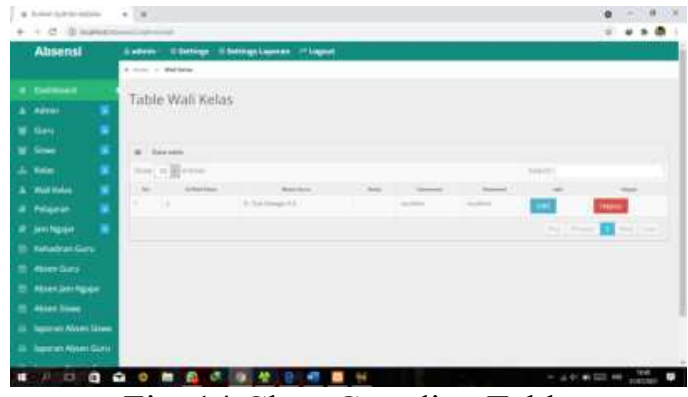

Fig. 14 Class Guardian Table

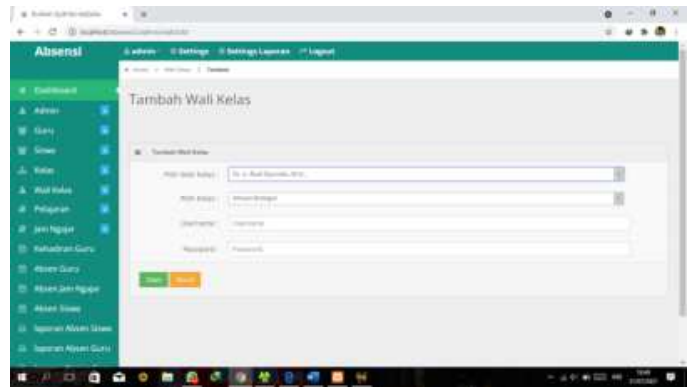

Fig. 15 Add Class guardian

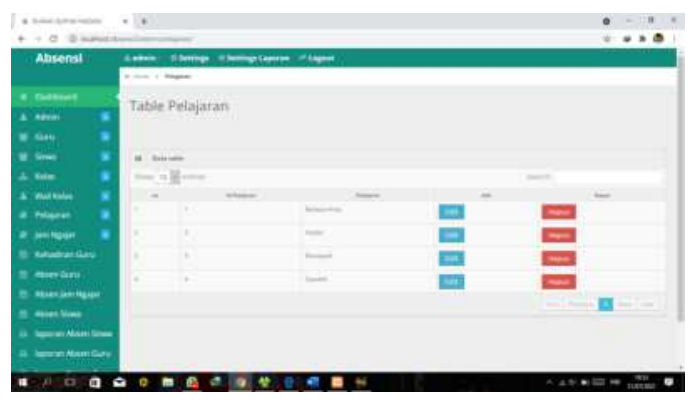

Fig. 12 Lesson Table

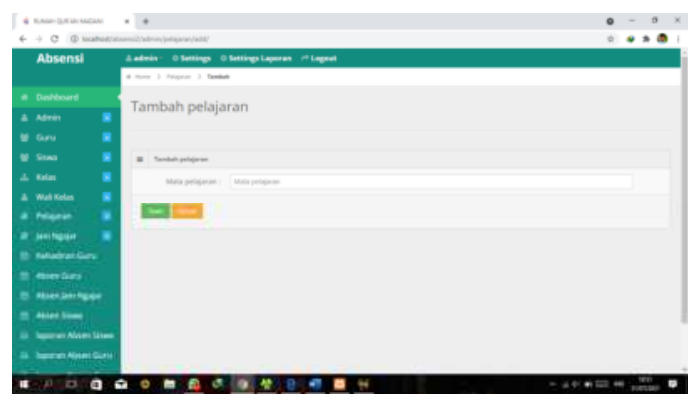

Fig. 13 Add Lessons

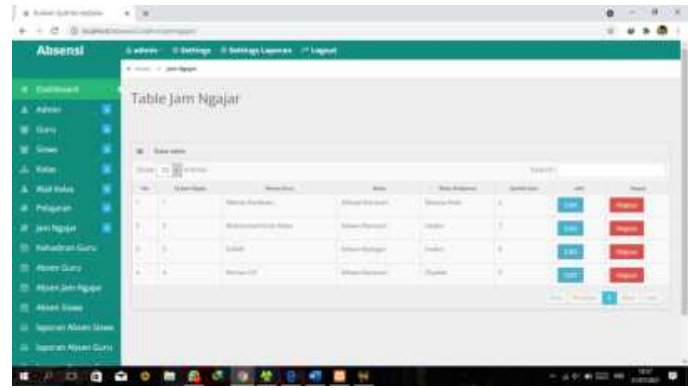

Fig. 14 Table Teaching Hours

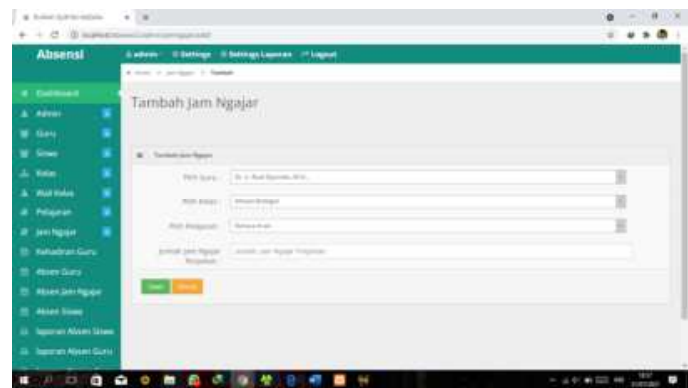

Fig. 15 Add Teaching Hours

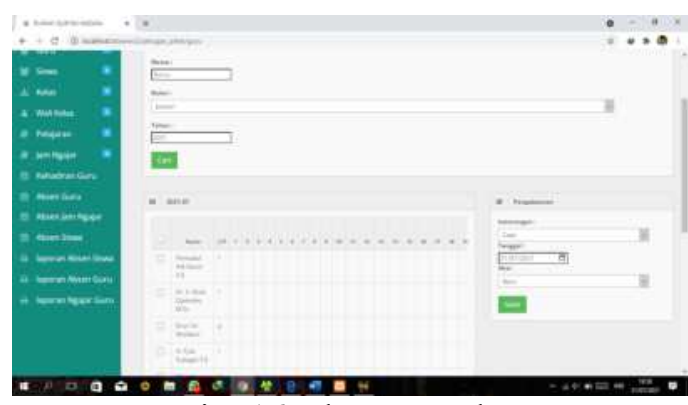

Fig. 16 Absent teacher

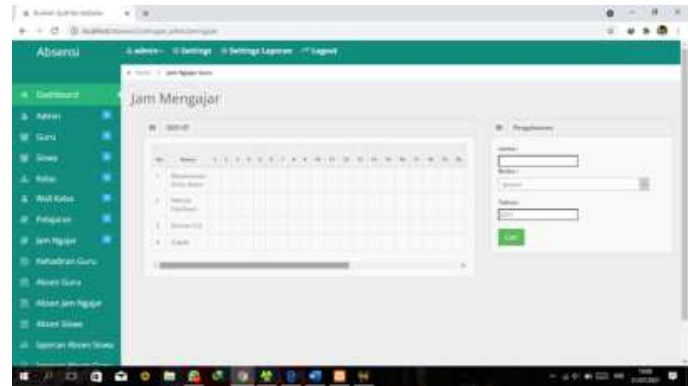

Fig. 17 Absent Ngajar Hours 


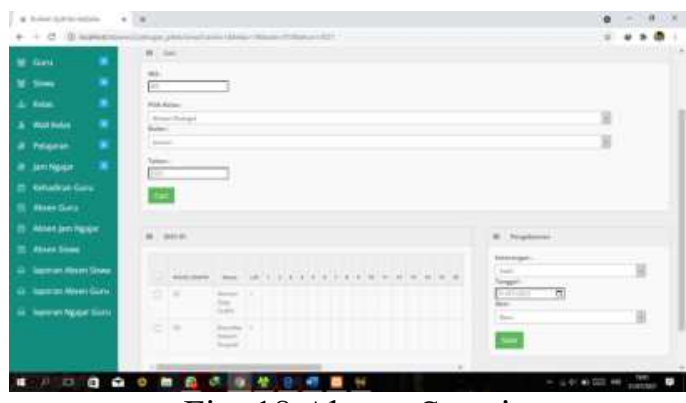

Fig. 18 Absent Santri

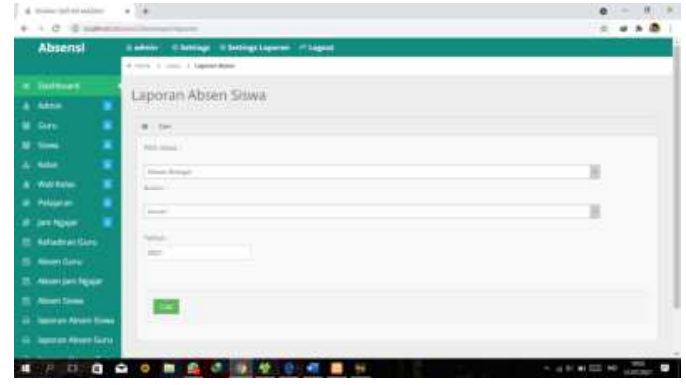

Fig. 19 Student Absentee Report

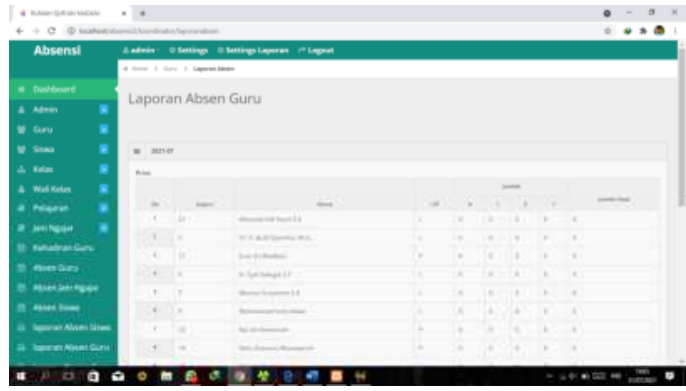

Fig. 20 Teacher Absence Report

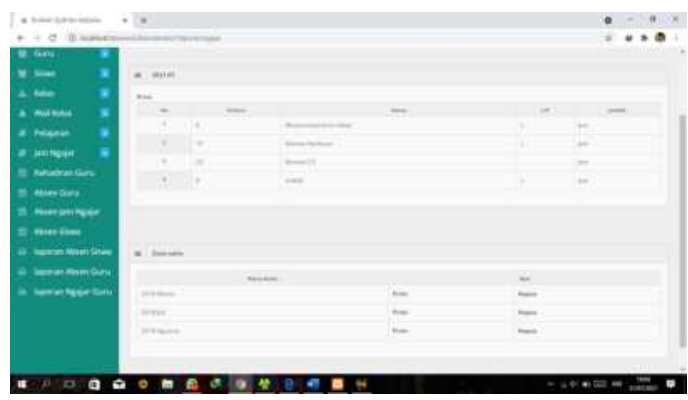

Fig. 21 Teacher's Report

\section{CONCLUSION}

This journal that has been created is the design of a webbased santri attendance information system in Rumah Yatim and Tahfidz Qur'an Madani which is expected to be useful to facilitate students and teachers in filling out absenteeism and to avoid fraud and data loss.

After the final discussion the author can make the following conclusions:
1. The santri attendance information system is designed to be able to monitor the presence of santri in the Orphanage and Tahfidz Qur'an Madani.

2. The attendance information system will design efficiently because it does not have to incur stationary costs such as paper, stationery, data archiving and having data security.

\section{SUGGESTION}

The design of this information system is still a lot of shortcomings for both the author and the Orphanage and Tahfidz Qur'an Madani. Therefore, the author provides roles for future improvement, namely: It is expected that the participation of the Orphanage and Tahfidz Qur'an Madani will be able to maintain and update the web-based santri absence system.

\section{REFERENCES}

[1] Abdul Kadir. Pengenalan Sistem Informasi. Yogyakarta, ANDI Yogyakarta, 2003.

[2] Ambarita, M. d. (2016) . Metode Penelitian Sistem Informasi: Mengatasi Kesulitan Mahasiswa dalam menyusun proposal Penelitan. Yogyakarta: Budi Utama

[3] Amin, M. M. (2010). In M. M. Amin, Pemgembangan Aplikasi Web Menggunakan PHP Data Object (PDO) (p.2. Yogyakarta: Graha Ilmu.

[4] Davis, G.B. (1999), Kerangka Dasar Sistem Informasi Manajemen Bagian 1 : Pengantar, Diterjemahkan oloeh Andreas, S, Ardiwardana, Jakarta.

[5] Elvia (2008), Merancang Sebuah Sistem Informasi Absensi Berbasis Web.

[6] Ghazali, M., dkk. 2008. Konsep Sistem Informasi, Yogyakarta : Andi Offset

[7] Hartono, Jogiyono. MBA, Ph.D. 1999. Analisis dan Desain Sistem informasi. ANDI, Yoyakarta. 2005.

[8] HM, Jogiyanto. (1999), Analisis dan Desain Sistem Informasi : Pendekatan Terstruktur Teori dan Praktek Aplikasi Absensi, Andi, Yogyakarta.

[9] Jogiyanto, HM. 2005. Analisis dan Design Sistem Informasi, Yogyakarta: Andi Offset

[10] Kadir, Abdul, Terra C.H., Trwahyuni. (2005), Pengantar Teknologi Informasi, Andi, Yogyakarta.

[11] Ladjamudin, 2005. Analisis dan Desain Sistem Informasi, Yoyakarta : Graha Ilmu. Menguasai XHTML, CSS, PHP \& MySQL Melalui Dreamweaver, (2009). Yogyakarta: Andi dan Madcoms.

[12] Perangin-angin, Kasiman. 2006. Aplikasi web dengan Php dan MySql. Yogyakarta : ANDI

[13] Sidik, Betha. (2012), Pemprograman Web dengan PHP (edisi revisi), Informatika Bandung.

[14] Supardi, Yuniar., Pascal dan Flowchart, Dinastindo, Jakarta, 2000.

[15] Sutabri,2005. Karakteristik - Karakteristik Sistem dan Klasifikasi Informasi. 